\title{
The Occurrence of Aeromonas spp. in the Bottled Mineral Water, well Water and Tap Water from the Municipal Supplies
}

\author{
Denise de Oliveira Scoaris ${ }^{1}$, Fernando Cezar Bizerra ${ }^{1}$, Sueli Fumie Yamada-Ogatta $^{2}$, \\ Benício Alves de Abreu Filho ${ }^{3}$, Tânia Ueda-Nakamura ${ }^{3}$, Celso Vataru Nakamura ${ }^{3}$ and \\ Benedito Prado Dias Filho ${ }^{3 *}$ \\ ${ }^{1}$ Programa de Pós-graduação em Microbiologia; Universidade Estadual de Londrina; Londrina - PR - Brasil. \\ ${ }^{2}$ Departamento de Microbiologia; Universidade Estadual de Londrina; Londrina - PR - Brasil. ${ }^{3}$ Departamento de \\ Análises Clínicas; Universidade Estadual de Maringá; Av. Colombo, 579; 87020-900; Maringá - PR - Brasil
}

\begin{abstract}
The aim of this work was to study the occurrence of Aeromonas sp in the bottled mineral water, well water and tap water from the municipal supplies. Positive samples were found for Aeromonas spp. $12.7 \%$ from the mineral water, $8.3 \%$ from the artesian water and $6.5 \%$ from the tap water. The recovery of Aeromonas spp. was significantly higher in the bottled mineral and artesian water than in the tap water from municipal supplies. The occurrence of the Aeromonas spp. did not correlate significantly with the contamination indicator bacteria (i.e. total coliforms) in the artesian water samples. However, a significant correlation was found between Aeromonas spp. and total coliforms in the both mineral water and tap water samples. The presence or absence of a correlation between the indicator bacteria and Aeromonas could reflect the occasional appearance of the pathogen in the drinking water and the different rates of survival and recovery of these agents compared with those fecal indicators. The finding that 41.6, 14.8 and $9.0 \%$ of the artesian water, bottled mineral water and tap water, respectively, sampled in the current study failed to meet the Brazilian standard for total coliforms in the drinking water should therefore be of concern.
\end{abstract}

Key words: Aeromonas, drinking water, indicator bacteria, coliforms

\section{INTRODUCTION}

The contamination of the natural water with the fecal materials, domestic and industrial sewage and run-off from the pasture and agricultural land may result in an increasing risk of the disease transmission to the human that use these waters (Wiggins, 1996, Nogueira et al., 2003). Therefore, to protect the consumers from the possible diseases transmitted by the water, it is important to monitor the occurrence levels of the pathogens in such water (Gray, 1994). Although there is concern about the incidence of the coliforms indicator group existing in water, the legislation do not preconize the search of the heterotrophic bacteria that also would be inhabiting the aquatic environment, growing up from the biodegradable organic matter (Haddix et al., 2004), working as

* Author for correspondence 
the indicators of the presence of the toxic substances in the water (Nocciolini et al., 2000). These microorganisms often act as the secondary pathogens, having the capacity to elicit the pathological episodes in the hosts subject to intense stress (Roitt et al., 1996).

Significant portions of this heterotrophic group are bacteria of Aeromonas genus. This group was included in the Vibrionaceae family, but since the 1980's, some researchers had proposed the classification of these in a new family, Aeromonadaceae (Colwell et al., 1986; Joseph and Carnahan., 1994; Holt et al., 1994), including three genus: Aeromonas, Ocealimonas e Tolumonas (ICSB, 2003). The aeromonads are mesophilic motile or psycrophilic non-motile Gram-negative bacteria (Lee et al., 2002), showing mobility by the polar flagellum (Holt et al., 1994).

Despite the fact that 19 named species have been classified, only few of them are recognized as human pathogens, such as A. hydrophila complex, A. caviae and A. veronii, representing almost $85 \%$ of the clinical isolates, although other species have been recovered from the clinical sources (Janda and Abbot, 1998). Aeromonads are also found in a variety of sources, such as the food (Granum et al., 1998; Cansian et al., 2005; Ullmann et al., 2005; Martin Talavea et al., 2006), natural water (Ghenghesh et al, 2001; Ørmen and Østensvik, 2001, Sousa and Silva-Souza 2001) and drinking water (Kuhn et al., 1997; Villari et al., 2003), and it is known that psycrophilic species are mainly etiologic agents in the fishes (Garduño et al., 2000). In human immunocompetent hosts, the members of this genus may be responsible for the intense gastroenteritis, called traveler's diarrhea (Janda and Abbot, 1998; Vila et al., 2003), but in the immunocompromised hosts, these bacteria could be implicated in the cases of myonecrosis, bacteremia, septicaemia (Martino et al., 1997) and hepatic cirrhosis and neoplasys (Chien Ko and Chuang, 1995).

The coliforms organisms have long been recognized as a suitable microbial indicator of the drinking-water quality, largely because they are easy to detect and enumerate in the water (WHO, 1993). In the drinking water from the municipal supplies, the coliforms test can be used as an indicator of the treatment efficiency and the integrity of the distribution system. Although the coliforms organisms may not always be directly associated to the presence of the fecal contamination, the presence of the coliforms in the drinking water suggests the potential presence of the pathogenic enteric microorganisms such as Salmonella spp., Shigella spp., and Vibrio cholerae. Coliforms bacteria are the only microbiological contamination to be regulated by the federal law in both the tap and bottled water. According to the Brazilian directives (ANVISA, 2004), at least 40 samples per month of the tap water from each public water supply should be analysed and the bacterial indicator must not be present in $95 \%$ of the samples taken throughout any 12-month period. In the case of minimum frequencies, one sample every week for the waterworks with surface water source and one sample every two weeks for the waterworks with a ground water source the indicator must not be detectable in any 100-ml sample.

The objective of this study was to determine the frequency of Aeromonas species in the bottled mineral, artesian water and tap water, as well as their correlation with the indicator bacteria.

\section{MATERIALS AND METHODS}

\section{Water samples and microbial enumeration}

A total of 238 samples of the drinking water taken from the bottled mineral water, artesian water and tap water from the municipal systems were investigated for Aeromonas. The mineral waters were purchased at the local supermarkets and, wherever appropriate, the bottles representing different batches within one brand were purchased. The samples of the artesian water were collected from the residences and workplaces of the city of Maringá supplied by the alternative water systems. After membrane the filtration of $250 \mathrm{ml}$ samples, the filters (Millipore HC filter, pore size $0.45 \mu \mathrm{m}$ ) were placed on the M-Endo Agar LES (M-Endo) to enumerate the total coliforms and on the MFecal Coliforms (M-FC) to enumerate the termotolerant coliforms, incubated at $37^{\circ} \mathrm{C}$ for 24 $\mathrm{h}$, and at $44.5^{\circ} \mathrm{C}$ for $24 \mathrm{~h}$, respectively (APHA, 1995). After the incubation period, the typical coliforms colonies were confirmed in Lauryl Triptose and EC broth. Atypical colonies (lactosenegative red or transparent in M-Endo and orange or transparent in M-FC) were Gram stained and identified as presumptive Aeromonas spp. if they were Gram-negative, oxidase-positive, glucosefermenting $(\mathrm{O} / \mathrm{F}$ test $)$ and resistant to vibriostatic agent $\mathrm{O} / 129 \quad(150 \mu \mathrm{g})$. The presumptive 
Aeromonas isolates were confirmed by the PCRbased assay as described below.

\section{Molecular identification}

The molecular identification, as the primers designs to amplify 16S rDNA gene (forward primer 5'- AGAGTTTGATCATGGCTCAG- 3' and reverse primer 5' GGTTACCTTGTTACGACTT-3'), were performed as Borrel et al., 1997. The presumptive Aeromonas genus isolated from the different water sources were examined. For genus-specific analysis, the DNA was extracted from the each bacterial sample (including the reference strains) by boiling during $10 \mathrm{~min}$. After the boiling, the DNA was stored at $-4^{\circ} \mathrm{C}$ until application on the PCR experiments. The PCRs were carried out on a thermal cycler Primus 96 Plus (MWGAG Biotech). A $20 \mu \mathrm{l}$ containing a final concentration of $50 \mathrm{mM} \mathrm{KCl}, 2 \mathrm{mM}$ Tris- $\mathrm{HCl}$ (ph 8.4), $1.5 \mathrm{mM}$ $\mathrm{MgCl}_{2}, 0.2 \mathrm{mM}$ of each deoxyribonucleotide triphosphate (dATP, dCTP, dGTP and dTTP) (Invitrogen), $2 \mathrm{U}$ taq I DNA polymerase (Invitrogen), $2 \mu \mathrm{l}$ aliquot of DNA sample, and $1 \mu \mathrm{l}$ of each primer (forward and reverse) was added for every reaction. The PCRs were performed under the following conditions: denaturation at $93^{\circ} \mathrm{C}$ for $10 \mathrm{~min}$, followed by 35 cycles at $94^{\circ} \mathrm{C}$ for $1 \mathrm{~min}, 56^{\circ} \mathrm{C}$ for $1 \mathrm{~min}$, and $72^{\circ} \mathrm{C}$ for $1 \mathrm{~min}$. After the final cycle, the extension at $72^{\circ} \mathrm{C}$ was allowed for $10 \mathrm{~min}$. The PCR products were precipitated with the addition of $10 \%$ volume of 3.0 M sodium acetate and $200 \mu \mathrm{l}$ of cold ethanol, dried and suspended on $25 \mu$ l of the sterile distilled water. Endonuclease digestion, electrophoresis and pattern analysis were performed as described by Borrel et al., 1997, with the modifications. The enzymatic digestion was performed by incubating $12 \mu \mathrm{l}$ of the amplification and precipitated products with $5 \mathrm{U}$ of each enzyme (AluI and MboI, Invitrogen) and $2 \mu \mathrm{l}$ of the corresponding 10X buffer (buffer A for AluI and $M b o \mathrm{I})$, in a total volume of $20 \mu \mathrm{l}$. The reaction mixture was incubated overnight at $37^{\circ} \mathrm{C}$. The electrophoresis on $10 \%$ poliacrilamida gel in $1 \mathrm{X}$ TBE (tris-borate-EDTA) buffer, for 2.5 hours on $70 \mathrm{~V}$ was made on aliquots of $10 \mu \mathrm{l}$ of each restriction reaction. The gels were stained by the silver method. The molecular sizes of the fragments obtained were estimated by the use of $100 \mathrm{pb}$ molecular marker used as reference.

\section{Statistical analysis}

Results were analyzed by the linear regression and t-test at $p<0.05$ and 0.005 of confidence level using the Statistical Analysis System software.

\section{RESULTS AND DISCUSSION}

In the present study, the positive samples for Aeromonas were $12.7 \%$ from the mineral water, $8.3 \%$ from the artesian water and $6.5 \%$ from the tap water (Table 1). The recovery of Aeromonas was significantly higher in the bottled mineral and artesian water than in the tap water from municipal supplies. The studies of Aeromonas spp. in drinking water and even in the chlorinated water supplies showed that this bacterium was isolated frequently (Knochel and Jeppesen, 1990; Alavandi et al., 1999).

Table 1 - Aeromonas, total coliforms and fecal coliforms in samples collected from bottled mineral water, artesian water and tap water from municipal supplies.

\begin{tabular}{|c|c|c|c|}
\hline \multirow[b]{2}{*}{ Microorganism } & \multicolumn{3}{|c|}{ Number of positive samples (percentage) } \\
\hline & $\begin{array}{c}\text { Bottled mineral water } \\
\qquad(\mathrm{n}=47)\end{array}$ & $\begin{array}{l}\text { Artesian water } \\
\qquad(n=24)\end{array}$ & $\begin{array}{c}\text { Tap water }^{b} \\
(n=167)\end{array}$ \\
\hline Aeromonas spp. & $6(12.7)$ & $2(8.3)$ & $11(6,5)$ \\
\hline Total coliforms & $7(14.8)$ & $10(41.6)$ & $15(9.0$ \\
\hline Fecal coliforms & 0 & $4(16.6)$ & $4(2.4)$ \\
\hline
\end{tabular}

${ }^{2} 201$ bottles

${ }^{\mathrm{b}}$ Most-often-used faucet

A correlation coefficient matrix was established to compare the degree of the association between Aeromonas spp. and the indicator bacteria (Table
2). Different results were observed with the samples from the bottled mineral water, artesian water and tap water from the municipal supply. 
The occurrence of the species of Aeromonas did not correlate significantly with the indicator bacteria in the mineral water samples. The lack of correlation between Aeromonas and total coliforms suggested that the two microorganisms could indicate different source of the pollution. However, a significant correlation was found between
Aeromonas and total coliforms in both the tap water and well water samples. The absence of a correlation between the indicator bacteria and Aeromonas could reflect the occasional appearance of the pathogens in the drinking water and the different rates of the survival and recovery of these agents compared with those fecal indicators.

Table 2 - Spearman correlation coefficients among Aeromonas and indicator bacteria.

\begin{tabular}{lcccccc}
\hline \multirow{2}{*}{ Microorganism } & \multicolumn{6}{c}{ Correlation coefficient } \\
\cline { 2 - 7 } & \multicolumn{2}{c}{ Mineral water $^{\mathbf{a}}$} & \multicolumn{2}{c}{ Artesian water } & \multicolumn{2}{c}{ Tap water $^{\mathbf{b}}$} \\
\hline $\mathrm{TC}^{\mathrm{c}}$ & 0.1981 & 0.000 & $0.4677^{*}$ & 0.3669 & $0.4472^{*}$ & $0.5291^{*}$ \\
$\mathrm{FC}^{\mathrm{d}}$ & 0.000 & - & 0.2941 & - & 0.1690 & \\
& Aeromonas & $\mathrm{FC}$ & Aeromonas & $\mathrm{FC}$ & Aeromonas & FC
\end{tabular}

Significance level: *p<0.05. ${ }^{\mathrm{a}}$ 20-litre bottles on water dispensers. ${ }^{\mathrm{b}}$ Municipal supply . ${ }^{\mathrm{c}}$ Total coliform group. ${ }^{\mathrm{d}}$ Fecal coliform group.

Other authors have found that the coliforms counts did not correlate with Aeromonas spp.( Legnani et al., 1998). Massa et al., (2001) reported that Aeromonas spp. could be good indicator of the hygienic quality of the water. They found a large number of Aeromonas in water, consequently their search should be used to indicate the unsatisfying conditions, especially in the private water systems that did not undergo systematic chlorine treatment. The finding that $41.6,14.8$ and $9.0 \%$ of the artesian water, bottled water and tap water (Table 1), respectively, sampled in the current study failed to meet the Brazilian standard for the total coliforms in the drinking water should, therefore, be of concern. This highlights the need for an improved surveillance system for both the bottled water industry and the municipal water supplies.

Since the biochemical characterization is not precise and time-consuming, several proposals have been made about the classification of the aeromonads, including the structural factures, such as the fatty acids methyl esters compositions (FAMES) (Canonica and Pisano, 1985; Canonica and Pisano, 1988) and genetic composition and variability (Soriano, et al., 1997; Kaznowski, 1998; Lee et al., 2002; Miñana-Galbis et al., 2004). The $16 \mathrm{~S}$ (or small subunit) rDNA sequences have been proven to be a valuable tool in the identification of most Aeromonas species (Martínez-Murcia, 1992), on the members of this genus exhibited very high levels of overall sequence similarity, reaching more than 98\% (Figueras et al., 2000). Nevertheless, only $2 \%$ of difference in the genetic composition of $16 \mathrm{~S}$ rDNA, which in nucleotides corresponded to 1-32 base differences (MartínezMurcia, 1992), could be enough to distinguish among the species of Aeromonas genus until species level by restriction fragments length polymorphism techniques (RFLP) of the amplicons of this conserved sequence (Borrel et al., 1997).

A total of 19 strains were isolated from M-Endo and M-FC media. The isolates were identified to the species levels by the RFLP-based method. The frequency of isolated is shown in Table 3 . Aeromonas spp. identified to the species level were A. hydrophila and A. jandaei. For the other strains, it was impossible identify to the species level with the tests used.

Table 3 - Frequency of isolation of Aeromonas spp. in bottled mineral, artesian water and tap water.

\begin{tabular}{lccc}
\hline \multirow{2}{*}{ Isolate } & \multicolumn{3}{c}{ No. of samples } \\
\cline { 2 - 4 } & Bottled mineral water & Artesian water & Tap water \\
\hline Aeromonas hydrophila & 2 & 0 & 2 \\
Aeromonas jandaei & 1 & 1 & 3 \\
Aeromonas spp. & 3 & 1 & 6 \\
\hline
\end{tabular}


The drinking water and food are reservoirs of Aeromonas species and therefore may be important sources of human infections. The bacteria of the genus Aeromonas have been frequently recognized as responsible for several diseases, both in the human and animals (Cahil, 1990; Krovacek et al., 1995). A. hydrophyla, A. caviae and A. sobria have been linked to two major groups of human diseases: septicemia and gastroenteritis (Merino et al., 1999). A greater risk of the infection is reported in the young children, elderly people, and immunocompromised patients (Janda, 1991). Several virulence factors have been identified in Aeromonas spp. (Turnbull et al., 1984; Ljungh, 1987; Cahil, 1990), as the heatlabile and heat-stable cytotoxin that have enterotoxic activities together the ability to produce the hemolysins and proteases. Another important attribute of the pathogenic Aeromonas species could be the production of adhesins (Burke et al., 1984). Several recent reports implicate aquatic environmental in Aeromonas-associated human infections (Baddour, 1992; King et al., 1992; Ghanem et al., 1993).

The public health significance of the large number of Aeromonas spp. that can develop in the water is unclear. Therefore, there is an urgent need to compare the effects of the strains belonging to each of these species in a wider range of the animal models of the infection. These results can contribute to the re-evaluation of the criteria used to determine the microbial quality of the drinking water and to define the measures for limiting Aeromonas densities in the drinking water.

\section{ACKNOWLEDGEMENTS}

This work was supported by the Conselho Nacional de Desenvolvimento Científico e Tecnológico (CNPq), Financiadora de Estudos e Projetos (FINEP), Coordenação de Aperfeiçoamento de Pessoal de Nível Superior (CAPES), Fundação Araucária, and Programa de Pós-graduação em Microbiologia da Universidade Estadual de Londrina

\section{RESUMO}

A porcentagem de amostras positivas para Aeromonas foi de $12.7 \%$ para água mineral, $8.3 \%$ para água de poço artesiano e $6.5 \%$ para água do sistema público de abastecimento. $\mathrm{O}$ isolamento de Aeromonas spp. foi significativamente maior em água mineral e água de poço artesiano do que em água do sistema público. A ocorrência de Aeromonas spp. não teve correlação significativa com os indicadores de contaminação tradicionalmente utilizados (coliformes totais) em amostras de água de poço artesiano. No entanto, esta correlação foi positiva e significativa em água mineral e água do sistema público. A presença ou ausência de correlação entre bactérias indicadoras e a presença de Aeromonas pode refletir o aparecimento ocasional de patógenos em águas para consumo humano e as diferentes taxas de sobrevivência e isolamento destes agentes comparados com os indicadores fecais de contaminação. A constatação de que $41.6 \%$, $14.8 \%$ e $9.0 \%$ respectivamente amostras de água de poço, água mineral e água do abastecimento público utilizadas neste estudo apresentaram índices de coliformes maiores do que os aceitáveis pela legislação brasileira é um fato preocupante. Estes números mostram a necessidade de melhoria nos sistemas de monitoramento para a indústria de águas minerais e o sistema público de abastecimento. As cepas isoladas pertencentes ao gênero Aeromonas foram identificadas ao nível de espécie como A. hydrophila e A. jandaei. A significância do grande número de isolamentos de espécies de Aeromonas em saúde pública ainda não está clara. É necessário o estudo dos efeitos de cepas específicas utilizando modelos animais de infecção. Estes resultados podem contribuir para a reavaliação dos critérios empregados para a análise da qualidade microbiológica da água e a definição de limites de densidades para o gênero Aeromonas em águas destinadas ao consumo humano.

\section{REFERENCES}

Agência Nacional de Vigilância Sanitária (ANVISA). (2000), Normas e padrão de potabilidade da água destinada ao consumo humano. http://elegis.bvs.br/leisref/public/search.php.

Alavandi, S.V., Subashini, M.S., Ananthan, S. (1999), Occurrence of haemolytic and cytotoxic Aeromonas species in domestic water supplies in Chennai, Indian. Journal Medical Research, 110, 50-55.

American Public Health Associtation (APHA). (1995), Standard methods for the examination of water and wastewater. 19th ed. Washington, DC. 
Baddour, M.D. (1992), Extraintestinal Aeromonas infections, Mayo Clinical Proceeding, 67, 496-498.

Borrel, N., Acinas, S. G., Figueras, M.-J., MartínezMurcia, A.J. (1997), Identification of Aeromonas clinical isolates by restriction fragment length polymorphism of PCR-amplified 16S rRNA genes, Journal of Clinical Microbiology, 35(7), 1671-1674.

Burke, V., Robinson, J. Gracey, M., Peterson, D. Partridge K. (1984), Isolation of Aeromonas hydrophila from a metropolitan water supply: seasonal correlation with clinical isolates, Applied and Environmental Microbiology, 48, 361-366.

Cahil, M. (1990), Virulence factors in motile Aeromonas species, Journal Applied Bacteriology, 69, 1-16.

Canonica, F.P., Pisano, M.A. (1985), Identification of hydroxy fatty acids in Aeromonas hydrophila, Aeromonas sobria and Aeromonas caviae, Journal of Clinical Microbiology, 22(6), 1061-1062.

Canonica, F.P., Pisano, M.A. (1988), Gas-liquid chromatographic analysis of fatty acid methyl esters of Aeromonas hydrophila, Aeromonas sobria and Aeromonas caviae, Journal of Clinical Microbiology, 26(4), 681-685.

Cansian, R.L., Floriani, S.T.R., Valduga, E. (2005), Microbiological analysis of critical points in the chicken industry, Brazilian Archives of Biology and Technology, 48, 403-406.

Chien Ko, W., Chuang, Y.C. (1995), Aeromonas bacteremia: review of 59 episodes, Clinical Infectious Diseases, 20, 1298-1304.

Colwell, R.R., MacDonell, M.T., DeLey, J. (1986), Proposal to recognize the family Aeromonadaceae, International Journal of Systematic Bacteriology, 36, 473-477.

Figueras, M.J., Soler, L., Chacón, M.R., Guarro, J., Martínez-Murcia, A.J. (2000), Extended method for discrimination of Aeromonas spp. by rDNA RFLP analysis, International Journal of Systematic and Evolutionary Microbiology, 50, 2069-2073.

Garduño, R.A., Moore, A.R., Olivier, G., Lizama, A.L., Garduño, E., Kay, W.W. (2000), Host cell invasion and intracellular residence by Aeromonas salmonicida: role of the S-layer, Canadian Journal of Microbiology, 46, 660-668.

Ghanem, E.S., Mussa, M.E., Eraki, H.M. (1993), Aeromonas-associated gastroenteritis in Egypt. Zentralbl Mikrobiol, 148(6), 441-447.

Ghenghesh, K.S., El-Ghodban, A., Dkakni, R., Abeid, S., Altomi, A., Tarhuni, A., Marialigeti, K. (2001), Prevalence, species differentiation, haemolytic activity and antibiotic susceptibility of Aeromonads in untreated well water, Memórias do Instituto Oswaldo Cruz, 96(2), 169-173.

Granum, P.E., O’Sullivan, K., Tomás, J.M., Ørmen, Ø. (1998), Possible virulence factors of Aeromonas spp. from food and water, FEMS. Immunology and Medical Microbiology, 21, 131-137.
Gray, N. F. (1994), Drinking water quality: Problems and solutions, ed. John Wiley and Sons, Chichester.

Haddix, P.L., Nancy, J.S., LeChevallier, W.M. (2004), Characterization of bioluminescent derivatives of assimilable organic carbon test bacteria, Applied and Environmental Microbiology, 70(2), 850-854.

Holt, J.G., Krieg, N.R., Sneath, P.H.A.; Staley, J.T., Williams, S.T. (1994), Bergey's Manual of Determinative Bacteriology, ed Williams and Wilkins.

ICSB - International Committee on Systematic Bacteriology, Subcommittee on the taxonomy of Vibrionaceae. Names of taxa covered by the ICSP Subcommittee on the Taxonomy of Aeromonadaceae, Vibrionaceae and related organisms. April, 2003. http://www.the-icsp.org/subcoms/vibrionaceae.htm

Janda, J.M. (1991), Recent advances in the study of the taxonomy, pathogenicity and infectious syndromes associated with Genus Aeromonas. Clinical Microbiology Reviews, 4, 397-410.

Janda, J.M., Abbot, S.L. (1998), Envolving concepts regarding the genus Aeromonas: an expanding panorama of species, disease presentations and unanswered questions, Clinical Infectious Diseases, 27, 332-344.

Joseph, S.W.; Carnahan, A. (1994), The isolation, identification and systematics of the motile Aeromonas species, Annual Review of Fish Disease. 4, 315-343.

Kaznowski, A. (1998), Identification of Aeromonas strains of different origin to the genomic species level, Journal of Applied Microbiology, 84, 423-430.

King, G.E., Werner, S.B., Kizer, K.W. (1992), Epidemiology of Aeromonas infections in Califormia, Clinical Infectious Diseases, 15, 449-452.

Knochel, S., Jeppesen, C. (1990), Distribution and characteristic of Aeromonas in food and drinking water in Denmark, International Journal of Food Microbiology, 10, 317-322.

Krovacek, K., Dumontet, S., Eriksson, E., Baloda, B. (1995), Isolation, and virulence profiles of Aeromonas hydrophyla implicated in an outbreak of food poisoning in Sweden, Microbiology and Immunology, 39, 655-661.

Kühn, I., Allestam, G., Huys, G., Janssen, P., Kerters, K., Krovacek, K., Stenström, T.-A. (1997), Diversity, persistence and virulence of Aeromonas strains isolated from drinking water distribution systems in Sweden, Applied and Environmental Microbiology, 63, 2708-2715.

Lee, C., Cho, J.-C., Lee, S.-H., Lee, D.-G., Kim, S.-J. (2002), Distribution of Aeromonas spp. as identified by $16 \mathrm{~S}$ rDNA restriction fragment length polymorphism analysis in a tout farm, Journal of Applied Microbiology, 93, 976-985.

Legnani, P., Leoni, E., Soppelsa, F., Burigo, R. (1998), The occurrence of Aeromonas species in drinking 
water supplies of an aera of the Dolomite mountains, Italy, Journal of Applied Microbiology, 85, 271-276.

Ljungh, A. (1987), Aeromonas-toxins and other virulence factors, Experientia, 43, 367-368.

Martin Talavera, B.M., Benassi, F.O., Von Specht, M.E., Quiroga, M.I., Garcia, M.I, Pucciarelli, A.B., Zubreski, M.E.L., Gutkind, G. (2006), Susceptibilities to carbapenems and presence of cphA gene on food-borne Aeromonas, Brazilian Archives of Biology and Technology. 49, 677-682

Martínez-Murcia, A., Benlloch, S., Collins, D. (1992), Phylogenetic interrelationships of members of the genera Aeromonas and Plesiomonas as determined by 16S ribosomal DNA sequencing: lack of congruence with results of DNA-DNA hybridizations, International Journal of Systematic Bacteriology, 42, 412-421.

Martino, R., Santamaria, A., Pericas, R.; Sureda, A.; Brunet, S. (1997), Acute rhabdomyolysis and myonecrosis complicating Aeromonas bacteremia in neutronic patients with hematologic malignancies: report of two cases, Haematologica, 82, 692-694.

Massa, S., Altieri, C., D'Angela, A. (2001), The occurrence of Aeromonas spp. in natural water and well water. International Journal of Food Microbiology, 63, 169-173.

Merino, S., Aguilar, A., Nogueras, M.M., Regue, M., Swift, S., Tomas, J.M. (1999), Cloning, sequencing, and role in virulence of two phospholipase (A1 and C) from mesophilic Aeromonas sp serogroup O:34, Infection and Immunity, 67, 4008-4013.

Miñana-Galbis, D., Farfán, M., Fusté, C., Lóren, G. (2004), Genetic diversity and population structure of Aeromonas hydrophila, Aer. bestiarium. Aer. Salmonicida and Aer. popoffi by multilocus enzyme electrophoresis (MLEE), Environmental Microbiology, 6(3), 198-208.

Nocciolini, S., Spadeafina, L., Vacri, M.R., Bacci, E. (2000), A simple bacterial index for relative water quality: preliminary application in the Ortobello lagoon (Tuscany, Italy), Chemosphere, 41, 10651069.

Nogueira, G., Nakamura, C.V., Tognim, M.C.B., Abreu Filho, B.A., Dias Filho, B.P. (2003), Microbiological quality of drinking water of urban and rural communities, Brazil, Revista de Saúde Pública, 37, 232-236.
Ørmen, Ø., Østensvik, Ø. (2001), The occurrence of aerolysin-positive Aeromonas spp. and their cytotoxicity in Norwegian water sources, Journal of Applied Microbiology, 90, 797-802.

Roitt, I., Brostoff, J., David, M. (1996), Immunology, ed Mosby, cap 15, New York.

Soriano, A.C., Castilho, J.A., Moral, C.H., Salazar, M.S., Marcos, J.Y, Carrasco, G.N. (1997), RFLPPCR analysis of the aroA gene as a taxonomic tool for the genus Aeromonas, FEMS Microbiology Letters, 156, 199-204.

Sousa, J.A., Silva-Souza, A.T. (2001), Bacterial community associated with fish ans water from Congonhas River, Sertaneja, Paraná, Brazil, Brazilian Archives of Biology and Technology, 44, 373-381.

Turnbull, P.C., Lee, J.V., Miliotis, M.D., Van de Walle, S., Koornhof, H.J., Jeffery, L., Bryant, T.N. (1984), Enterotoxin production in relation to taxonomic grouping and source of isolation of Aeromonas species, Journal of Clinical Microbiology, 19, 175180.

Ullman, D., Krause, G., Knabner, D., Weber, H., Beutin, L. (2005), Isolation and characterization of potentially human pathogenic, citotoxin-production Aeromonas strains from retailed seafood in Berlin, Germany, Journal of Veterinary Medicine, 52, 82-87.

Vila, J., Ruiz, J., Gallardo, F., Vargas, M., Soler, L., Fiqueras, M.J., Gascon, J. (2003), Aeromonas spp. and traveler's diarrhea: clinical features and antimicrobial resistance, Emerging Infectious Diseases, 9(5), 552-555.

Villari, P., Crispino, M., Motuori, P., Boccia, S. (2003), Molecular typing of Aeromonas isolates in natural mineral waters, Applied and Environmental Microbiology, 69(1), 697-701.

Wiggins, B. A. (1996), Discriminate analysis of antibiotic resistance patterns in fecal streptococci, a method to differentiate human and animal source of fecal pollution in natural waters, Applied and Environmental Microbiology, 63, 3997-4002.

World Health Organization (WHO). (1993), Guidelines for drinking-water quality. $2 \mathrm{a}$ ed. Geneva. http://www.who.int/water_sanitation_health/. 